\title{
Historic and Teaching Aspects of Anatomy and Cebus Genus Role in Contemporary Anatomy
}

\author{
Aspectos Históricos y de Enseñanza de la Anatomía \\ y el Papel del Género Cebus en la Anatomía Moderna \\ ","** Gabriel de Abreu Pfrimer; ,"** Tainá de Abreu; ,"** Vanessa Souza Vieira; *"Nayane Peixoto Soares; \\ "Roqueline A. G. M. F. Aversi-Ferreira; "Lúcia Helena Almeida Gratão; "Guilherme Nobre \\ Lima do Nascimento; ${ }^{* * *}$ Hisao Nishijo \& "Tales Alexandre Aversi-Ferreira
}

PFRIMER, G. A.; ABREU, T.; VIEIRA, V. S.; SOARES, N. P.; AVERSI-FERREIRA, R. A. G. M. F.; GRATÃO, L. H. A.; NASCIMENTO, G. N. L.; NISHIJO, H. \& AVERSI-FERREIRA, T. A. Historic and teaching aspects of anatomy and Cebus genus role in contemporary anatomy. Int. J. Morphol., 30(2):607-612, 2012.

SUMMARY: Anatomy is the science that studies the body and a basic discipline in health and biological sciences indispensable to students that study this area, and plays a important role in the comparison of species. Nowadays anatomy is falling into academic and scientific crisis. Recently, the number of papers and reviews on health science education have increased considerably. Pre-clinical disciplines are essential for all health and biological science courses; among them anatomy is considered to be the basis of morphological sciences. For that reason, throughout history, this discipline has been viewed as a factual knowledge base that must be learned in its entirety. History of anatomy demonstrated that teaching in this area is facilitated by the use of dissection of both animal and human disciplines. In absence of human cadavers, it is possible to use animals for dissection for the benefits of students. The aim of this paper is to serve as a reminder to understand that anatomy is the basis of current health science and to realize what is important in the teaching of anatomy. It is also important to learn anatomy since researchers sometimes draw wrong conclusion because of lack of anatomical knowledge.

KEY WORDS: Anatomy' history; Anatomy's teaching; Capuchin monkeys; Cebus.

\section{HISTORIC ASPECTS}

Anatomy is the science that studies the body (Gardner et al., 1978), and a basic discipline in health and biological sciences indispensable to students that study this area (Nóbrega \& Tavares, 2008), and plays a important role in comparison of species (Aversi-Ferreira et al., 2005b).

The term "anatomy" is derivative from the Greek word anatome ("ana" means parts; "tome" means cut), and its method is dissection, which is derivate of the word dissecare from Latin ("dis" means separate; "secare" means cut) (Gardner et al.). Therefore, anatomy is a scientific discipline, and dissection is a technique to study the body structures (Moore \& Dalley, 2007).

Data from literature indicate that intellectual development of anatomy started in Europe with the Greeks who were interested in understanding the body (Malomo et al., 2006). Alaemaeon of Croton (500 B.C.) reported the most ancient anatomic observations (Gardner et al.) by dissection of animals because the ethics and religious precepts did not allow human dissection (Lyons \& Petrucelli, 1997). Some years after him, Hippocrates of Cos (460-380 B.C.), who is considered to be the medicine's father (Gardner et al.) because he released this area from mysticism and magic (Malomo et $a l$.). He removed cure by gods, put it in men's hands (Oliveira, 2005), and was also a founder of anatomic science giving clear information about practical procedures and surgery instruments in many books; on ancient medicine, on joints, The Book of Prognostics, on fistulae, on fractures, on hemorrhoids, on injuries of the head, instruments of reduction, on surgery and others that are not specific to medicine or anatomy.

\footnotetext{
* Laboratory of Anthropology, Biochemistry, Neuroscience and Primates' Behavior (LABINECOP), Federal University of Tocantins, Palmas, Tocantins, State, Brazil.

** Master Course in Veterinary Sciences, Veterinary School, Federal University of Uberlândia, Uberlândia, Minas Gerais State, Brazil.

*** System Emotional Science, University of Toyama, Toyama, Japan.
} 
PFRIMER, G. A.; ABREU, T.; VIEIRA, V. S.; SOARES, N. P.; AVERSI-FERREIRA, R. A. G. M. F.; GRATÃO, L. H. A.; NASCIMENTO, G. N. L.; NISHIJO, H. \& AVERSI-FERREIRA, T. A. Historic and teaching aspects of anatomy and Cebus genus role in contemporary anatomy. Int. J. Morphol., 30(2):607-612, 2012.

Aristotle (384-322 B.C.) is considered the founder of comparative anatomy (Gardner et al.) because he represented dissected animals in the books History of Animals, Parts of Animals, Movement of Animals, Progression of Animals and Generation of Animals. His disciple, Theophrastus of Ereso (? - 287 B.C.), denominated "dissection" of anatomy, and this word became generalized, and was accepted in all fields of biology that study the shapes and structures of organic beings, regardless of existing or extinct animals.

The first attempt of systematic human dissection was conducted by Herophilus (335-280 B.C.) and Erasistratus (310-250 B.C.), who also are called the fathers of anatomy and physiology, respectively. They were the founders of the Medical School of Alexandria, and dissected human bodies together, putatively using vivisection. Herofilus, who studied the brain and recognized that the brain was a center of the neural system and intelligence, dissected and described seven pairs of cranium nerves, distinguished nerves, blood vessels and motor and sensory nerves. He also studied the eyes, liver, digestive tract, pancreas and the genital apparatus. Erasistratus studied the heart, and discovered the valves, but dismissed how they worked in the heart.

In 150 B.C., dissection of human body was prohibited (see above) and anatomical studies were conducted using animal bodies (Lyons \& Petrucelli). It is not an overstatement that all anatomies started based on animal dissection and veterinary anatomy, which were compared in order to understand the human body.

Ruphus of Ephesus (late first century) wrote the first book dealing with anatomic nomenclature entitled ' $O n$ the Names of the Parts of the Human Body', and other books about medicine (diseases of the bladder and kidneys, satyriais and gonorrhea, and medical questions). He discovered that nerves originated from the brain and differentiated their motor and sensory parts, and tried to differentiate the cerebellum from the brain. He also studied the eyes minutely, and considered that the heart was fundamental to life and that the spleen was useless. Around 50 years after him, Soranus of Ephesus (90-150) described the uterus anatomy in the book Gynaecology, the first biography of Hippocrates (Life of Hippocrates), and other books on medicine such as on acute and chronic diseases, signs of fractures, bandages, introduction to the science of medicine (considered to be apocryphal).

In the centuries II and III, Claudius Galenus (129217) dissected animals, mainly monkeys and pigs, and extrapolated the human body from these observation in animals. However, he mistook, probably because the observations were not confirmed by comparison with human data (Lyons \& Petrucelli), and also because of few anatomists, scarce optic resources and difficulty to keep the dissected materials for later studies. Galenus distinguished sensory and motor nerves, veins, considered the brain as controller of the body, and descibed the heart. He also demonstrated that the kidney processes urine and that the arteries were filled with blood but not air, distinguished bones with and without medulla, and devised a surgical tool for cataracts. Galenus was the most important physician for about 1,200 years.

Long after Galen and the philosophy stagnation in Middle Age, human dissection was realized in the XIV century in Italy and France. According to Petrucelli (1997), the anatomic studies using humans started at that time, because of practical reasons rather than scientific ones; to identify the causes of death, mainly those of important persons, and also to verify causes of diseases. Mondino of Luzzi (1315) performed public dissections in Bologna and wrote the book entitled "Anatomia".

The artists collaborated much and contributed to development of anatomy, and this relationship might stem from pre-historical times since a cave painting indicated the mammoth heart in the correct place (Queiroz, 2005). It was in the Renaissance era that the anatomical knowledge evoked interests in artists including Leonardo Da Vinci, Michelangelo, Buonarotti, Johannes of Ketham, Berengario of Capri, Donatello, Rafael Sanzio (Malomo et al.), who wished to realistically paint the human body by dissection (Lyons \& Petrucelli). Leonardo Da Vinci (1452-1519) conducted dissection of human cadavers and designed details of adult and fetal human structures.

At that time, the union between art and anatomy as well as invention of printing promoted the publication of anatomical books including illustrations, the first was the book "Comments about Mondino" published in 1521 by Jacob Berengario of Capri (1470-1555) (Gardner et al.).

Modern anatomy started with publication of the book by Andreas Vesalius (1514-1564), "De humani corporis fabrica libri septem" in 1543 (Gardner et al.), which was the most complete anatomical work until then, and considered to be the most influential in all history of human anatomy. Vesalius decided not to consider Galen's data, and started to dissect human cadavers at the University of Padua where he was professor of anatomy and surgery. As expected, some data were not consistent with Galen's data. Subsequently, Vesalius published the book Opera Omnia where mistakes in Galen's work were corrected (Singer, 1996; O`Malley \& Sanders, 2002). Vesalius started scientific anatomy, and 
PFRIMER, G. A.; ABREU, T.; VIEIRA, V. S.; SOARES, N. P.; AVERSI-FERREIRA, R. A. G. M. F.; GRATÃO, L. H. A.; NASCIMENTO, G. N. L.; NISHIJO, H. \& AVERSI-FERREIRA, T. A. Historic and teaching aspects of anatomy and Cebus genus role in contemporary anatomy. Int. J. Morphol., 30(2):607-612, 2012.

taught anatomy using dissection and avoided teaching using figures (Letti, 1972; Singer; Margotta, 1998; O`Malley \& Sanders; Van De Graaff, 2003).

Pierre Belon (1517-1564) in France, who worked on "L'Historie de la Nature des Oyseaux" (The Story of the Nature of the Birds) published in 1555. This was the first work on comparative anatomy. Hieronymus Fabricius (15371619), the successor to Fallopio (1523-1562), is considered to be the father of Embryology. He taught anatomy at the University of Padua with Willian Harvey and Speigel, and designed the first permanent theater for public dissections in 1594. He studied fetus development from animal dissections and the digestor tract, eyes, ear and larynx, and described the Sylvius's fissure in the brain for the first time; these works were published in 1600 in Tabulae Pictae. Volcher Coiter (1534-1576) studied the comparative anatomy of the bones and the meningitis, and published Externarum et Internarum Principalium Humani Corporis Partium Tabulae (1573) and De Avium Sceletis et Praecipius Musculis (1575). Together, these three were the major comparative anatomists in century XVI.

In 1628, William Harvey (1578-1657) introduced the association between anatomy and physiology in his work "Exercitatio anatomica de motucordis et sanguinis in animalibus". He discovered great circulation. However, Rene Descartes (1596-1650) noted covertly the existence of great circulation because he was afraid to be excommunicated by Romaine Churchill.

In gross anatomy after century XVII, anatomists mainly cataloged the data and gave many names to the same structures because of difficulty in communication among scientists and in the creation of eponymies. It is noteworthy that young English physician Henry Gray (1825-1861) published the first edition of "Gray's Anatomy" in 1858 with 750 pages and 363 figures. The later editions were results of collective efforts by other anatomists, and the 40th edition was published in 2008 in honor of 150th birthday of first edition (Standring, 2008), entitled Gray's Anatomy: The Anatomical Basis of Clinical Practice with 1551 pages and more than 2,000 images.

Contemporary anatomy began after the first International Congress of anatomy in 1895 in the BasileiaSwiss to consolidate anatomy by unification of nomenclature because, at that time, there were around 50,000 anatomic names for 5,000 structures, and the majority were eponyms (Hollinshead, 1980).

The official anatomic terms were based on Latin, and translated to equivalent terms in each country's national vernacular to facilitate understanding and to avoid confusion, and the eponyms were eliminated as possible (Didio, 2000).

\section{ANATOMY TEACHING}

Nowadays the anatomy is falling into academic and scientific crisis. Recently, the number of papers and reviews on health science education have increased considerably (Cook \& Beckman, 2010). Pre-clinical disciplines are essential for all health and biological science courses; among them, anatomy is considered to be the basis of morphological sciences (Aversi-Ferreira et al., 2010a). For that reason, throughout the history, this discipline has been viewed as a factual knowledge base that must be learned in its entirety (Disnmore et al., 1999).

Recently, many health science schools are diminishing the curriculum time (Leung et al., 2006) and reducing the time allotted to traditional basic science disciplines (Aversi-Ferreira et al., 2010a). In this context, traditional anatomy based on topographical structural teaching by didactic lectures and dissection of the body with personal tuition has been replaced by a multiple range of special study modules such as problem-based workshops, computers, plastic models and many other teaching tools (Aziz et al., 2002; Biasutto et al., 2006). In some centers, dissected cadaver-based anatomy is no longer taught (Biasutto et al.).

On the other hand, many researchers do not consider what kind of science anatomy is. They have forgotten that current health sciences are dependent on anatomical data in clinical and surgery aspects, and in phylogeny, taxonomy and evolution (Flores, 2006). Moreover, since anatomy of many species has not been established (Aversi-Ferreira et al., 2009), it is difficult to construct evolutionary tree, mainly that of primates from New World (Aversi-Ferreira et al., 2010b).

On teaching of anatomy, there are many problems such as time reduction, diminution of practical dissection, high cost to keep laboratories, and few trained professionals and inappropriate methodology (Mclachlan \& Patten, 2006; Leung et al.; Nóbrega \& Tavares, 2008; Aversi-Ferreira et al., 2010a). In general, low academic performance in students is noted, for example, difficulty to memorize structures, is ascribed to inadequate preparation of pieces and cadavers and the inadequate way of teaching (Braz, 2009).

However, to minimize these problems anatomic researchers and educators published papers indicating how important dissection is as a teaching resource (Flores; 
PFRIMER, G. A.; ABREU, T.; VIEIRA, V. S.; SOARES, N. P.; AVERSI-FERREIRA, R. A. G. M. F.; GRATÃO, L. H. A.; NASCIMENTO, G. N. L.; NISHIJO, H. \& AVERSI-FERREIRA, T. A. Historic and teaching aspects of anatomy and Cebus genus role in contemporary anatomy. Int. J. Morphol., 30(2):607-612, 2012.

McLachlan \& Patten; Aversi-Ferreira et al., 2009; Leung et al.; Sugand et al., 2010). In fact, the major advantage in dissection practice is to permit students to construct their own knowledge by themselves because action of dissection requires students to associate previous knowledge acquired in classes, text books and observations in atlas with the dissected structures (Aversi-Ferreira et al., 2010b). Students subsequently process the data via visual, tactil, and kinesthetic experiences together with the manual activities (Aversi-Ferreira et al., 2009), stimulating reasoning and reflections to construct their own reality.

Moreover, other benefits of dissection are to form three dimensional and real images from structures, to facilitate learning of names of structures, to distinguish between normal and pathological structures, and to develop fine motor coordination (McLachlan \& Patten; Leung et al.; AversiFerreira et al., 2009). Works during dissection require concentration, interpretation and anatomical methods. Therefore, dissection is suitable to initial training for professional activities and understanding of scientific methods (Aversi-Ferreira et al., 2009). Thus, when it is not possible to dissect human body, the use of animal body instead of human body provides students with substantial benefits.

\section{THE ROLE OF CEBUS GENUS IN COMPARATIVE STRUCTURES}

The Cebus genus is most widely distributed in the world among neotropical primate species. They are observed from Colombia and Venezuela all the way to northern Argentina, and inhabit tropical, subtropical and riverside forests, as well as savannah and semi-arid regions of Brazil (Lopes, 2004).

Non-human primates constitute an important group among animals subjected to various studies. Ethological, evolutionary and paleontological studies have revealed changes in anatomical structures linked to evolution of primates (Tobias, 1971; Tobias, 1995; Holloway, 1973; Holloway, 1995), and contributed to comparative anatomy between Cebus libidinosus (C. libidinosus) and other neotropical monkeys or those from the Old World. The detailed knowledge on their anatomy might be important for their preservation and protection when the animals are brought to veterinary clinics after accidents or illnesses (Kindlovits, 1999).

The primatologists recognize that these animals have large cognition capacity, characteristics similar to Old World primates such as tool use (Christel \& Fragaszy, 2000), and high social organization capacity based on information transmits and learning of behavior (Resende et al., 2003).

However, the study of Cebus anatomy by AversiFerreira et al. $(2010 \mathrm{~b}, 2011 \mathrm{~b})$ indicated that tool use in previous studies were not complete because of absence of anatomical evidence in Cebus for tool use. For example, to justify manual abilities in Cebus, researchers cited that this primate uses the "lateral opponens" of thumb (Fragazy et al., 2010; Napier, 1980). However, this is wrong because the opponens is clearly defined in anatomy, and the fact that Cebus can touch the thumb with lateral part of the hand can not indicate existence of the opponens, although these primates have high manual abilities. Then, the anatomical study demonstrated that Cebus have the abductor pollicis longus muscle, and it is the unique non-human primate that has the extensor pollicis brevis muscle, and both muscles permit high mobility of the thumb in direction to extension (Aversi-Ferreira et al., 2010b; Aversi-Ferreira et al., 2011b). Therefore, manual ability of Cebus' thumb is not associated with the opponens, but with different and complex organization of the extensor muscles.

Other example opposite to that expected is that, in spite of similarities to chimpanzees in terms of cognitive ability and tool use, the thoracic anatomy of Cebus is more similar to that in baboons than in chimpanzee (AversiFerreira et al., 2005a,b, 2006, 2007a,b,c, 2009. 2010ab).

These data indicate the importance of anatomy in other sciences to avoid mistakes in conclusions. The anatomy of not only Cebus genus but also the majority of neotropical primates is not well studied, and new discoveries mainly in taxonomy and evolution are waiting for keen observers.

Examples of Cebus anatomy noted above indicate that this genus is offering a new way to comparative anatomy, i.e., the use of anatomy to justify their behavior.

\section{FINAL CONSIDERATIONS}

History of anatomy demonstrated that teaching in this area is facilitated by the use of dissection of both animal and human disciplines. In absence of human cadavers, it is possible to use animals for dissection for the benefits of students.

The examples in Cebus studies demonstrated the importance of anatomy in many areas, provide the behavioral studies with the anatomical basis, and open a new vision to study the neotropical primates and other animals. 
The aim of this paper is to serve as reminder to understand that the anatomy is the basis of current health science and to realize what is important in the teaching of anatomy. It is also important to learn anatomy since researchers sometimes draw wrong conclusion because of a lack of anatomical knowledge.
ACKNOWLEDGMENTS. This work was supported partly by CREST (Core Research for Evolutional Science and Technology), JST (Japan Science and Technology Agency), Japan, JSPS (Japan Society for the Promotion of Science) Asian Core Program, and the Ministry of Education, Science, Sports and Culture, Grant-in-Aid for Scientific Research (A) (22240051); and by CNPq (National Council of Technology and Development - Brazil).

PFRIMER, G.A.; ABREU, T.; VIEIRA, V. S.; SOARES, N. P.; AVERSI-FERREIRA, R. A. G. M. F.; GRATÃO, L. H. A.; NASCIMENTO, G. N. L.; NISHIJO, H. \& AVERSI-FERREIRA, T. A. Aspectos históricos y de enseñanza de la anatomía y el papel del género Cebus en la anatomía moderna. Int. J. Morphol., 30(2):607-612, 2012.

RESUMEN: La anatomía es la ciencia que estudia el cuerpo y una disciplina básica en ciencias de la salud y biológicas, indispensables para los estudiantes que tratan esta materia, teniendo además, un importante papel en la comparación de las especies. Actualmente, la anatomía está en una crisis académica y científica. Por otra parte, recientemente, el número de artículos y revisiones en la educación en ciencias de la salud han aumentado considerablemente. Las disciplinas pre-clínicas son esenciales para todos los cursos de salud y ciencias biológicas, entre ellas, la anatomía es considerada como la base de las ciencias morfológicas. Por esa razón, a lo largo de la historia, la anatomía ha sido considerada como una base de conocimiento de los hechos que deben ser aprendidas en su totalidad. La historia de la anatomía ha demostrado que la enseñanza en esta área se ve facilitada por el uso de la disección de animales. En ausencia de cadáveres humanos, es posible utilizar los animales para la disección, generando así beneficios para los estudiantes. El objetivo de este trabajo fue recordar el pasado para entender que la anatomía es la base de la ciencia de la salud actual y darse cuenta de la importancia de la enseñanza de esta disciplina. Finalmente, es importante recordar que los investigadores algunas veces han llegado a conclusiones erróneas debido a la falta de conocimiento sobre temas anatómicos.

PALABRAS CLAVE: Historia de la anatomía; Enseñanza de la anatomía; Monos capuchinos; Cebus.

\section{REFERENCES}

Aversi-Ferreira, T. A.; Aversi-Ferreira, R. A. G. M. F.; Silva, Z.; Gouvêae- Silva, L. F. \& Penha-Silva, N. Estudo anatômico de músculos profundos do antebraço de Cebus apella (Linnaeus, 1766). Acta Sci. Biol. Sci., 27(3):297-301, 2005a.

Aversi-Ferreira, T. A.; Lima-e-Silva, M. S.; Pereira-de-Paula, J.; Gouvêae-Silva, L. F. \& Penha-Silva N. Anatomia comparativa dos nervos do braço de Cebus apella.Descrição do músculo dorsoepitroclear. Acta Sci. Biol. Sci., 27(3):291-6, 2005 b.

Aversi-Ferreira, T. A.; Vieira, L. G.; Pires, R. M.; Silva, Z. \& PenhaSilva, N. Estudo anatômico dos músculos flexores superficiais do antebraço no macaco Cebus apella. Biosci. J., 22(1):139-44, 2006.

Aversi-Ferreira, T. A.; Pereira-de-Paula, J.; Lima-e-Silva, M. S. \& Silva, Z. Anatomy of the arteries of the arm of Cebus libidinosus (Rylands et al., 2000) monkeys. Acta Sci. Biol. Sci., 29:247-54, 2007a.

Aversi-Ferreira, T. A.; Pereira-de-Paula, J.; Prado, Y. C. L.; Lima-eSilva, M. S. \& Mata, J. R. Anatomy of the shoulder and arm muscles of Cebus libidinosus. Braz. J. Morphol. Sci., 24(2):63$74,2007 \mathrm{~b}$.

Aversi-Ferreira, T. A.; Pereira-de-Paula, J. \& Lima-e-Silva, M. S. Estudo anatômico das artérias do ombro de Cebus libidinosus (Rylands, 2000; Primates - Cebidae). Ciênc. Ani. Bras., 8(2):273-84, 2007c.

Aversi-Ferreira, T. A.; Lopes, D. B.; Reis, S. M.; Abreu, T.; AversiFerreira, R. A. G. M. F.; Vera, I. \& Lucchese, R. Practice of dissection as teaching methodology in anatomy for nursing education. Braz. J. Morphol. Sci., 26(3-4):151-7, 2009.
Aversi-Ferreira, T. A.; Nascimento, G. N. L.; Vera, I. \& Lucchese, R. The Practice of Dissection as Teaching Methodology in Anatomy Applied to Medical Education. Int. J. Morphol., 28(1):265-72, 2010a.

Aversi-Ferreira, T. A.; Diogo, R; Potau, J. M.; Bello, G.; Pastor, J. F. \& Aziz, A. M. Comparative Anatomical Study of the Forearm Extensor Muscles of Cebus libidinosus (Rylands et al., 2000; Primates, Cebidae), Modern Humans, and Other Primates, With Comments on Primate Evolution, Phylogeny, and Manipulatory Behavior. Anat. Rec., 293:2056-70, 2010 b.

Aversi-Ferreira, R. A. G. M.; Marin, K. A; Silva, F. O. \& Aversi-Ferreira, T. A. Comparative anatomy of the thigh nerve of Cebus libidinosus (Rylands et al., 2000). Pesq. Vet. Bras., 31(3):261-6, 2011 a.

Aversi-Ferreira, T. A.; Maior, R. S.; Carneiro-e-Silva, F. O; AversiFerreira, R. A. G. M. F; Tavares, M. C; Nishijo, H. \& Tomaz, C. Comparative Anatomical Analyses of the Forearm Muscles of Cebus libidinosus (Rylands et al. 2000): Manipulatory Behavior and Tool Use. PLoS One, 6(7):1-8, $2011 \mathrm{~b}$.

Aziz, M. A.; Mckenzie, J. C.; Wilson, J. S.; Cowie, R. J.; Ayeni, S. A. \& Dunn, B. K. The human cadaver in the age of biomedical informatics. Anat. Rec., 269:20-32, 2002.

Biasutto, S. N.; Caussa, L. I. \& Del Rio, L. E. C. Teaching anatomy? Cadaver vs. computer. Ann. Anat., 188:187-90, 2006.

Braz, P. R. P. Método didático aplicado ao ensino da anatomia $\mathrm{Hu}-$ mana. Anuário Prod. Acad. Docente, 39(4):303-10, 2009.

Christel, M. I. \& Fragaszy, D. Manual function in Cebus apella. Digital mobility, preshaping, and endurance in repetitive grasping. Int. J. Primatol., 21:697-719, 2000. 
PFRIMER, G. A.; ABREU, T.; VIEIRA, V. S.; SOARES, N. P.; AVERSI-FERREIRA, R. A. G. M. F.; GRATÃO, L. H. A.; NASCIMENTO, G. N. L.; NISHIJO, H. \& AVERSI-FERREIRA, T. A. Historic and teaching aspects of anatomy and Cebus genus role in contemporary anatomy. Int. J. Morphol., 30(2):607-612, 2012.

Cook, D. A. \& Beckman, T. J. Reflections on experimental research in medical education. Adv. Health Sci. Educ., 15:455-64, 2010.

Didio, L. J. A. Lançamento oficial da Terminologia Anatomica em São Paulo: um marco histórico para a medicina brasileira. Rev. Ass. Med. Brasil., 46(3):191-3, 2000.

Dinsmore, C. E.; Daugherty, S. \& Zeitz, H. J. Teaching and learning gross anatomy: Dissection. Prosection, or both of the above? Clin. Anat., 12:110-4, 1999.

Flores, B. G. M. What the Dissection Meaning for Medical Students. Int. J. Morphol., 24:575-80, 2006.

Fragaszy, D.; Pickering, T.; Liu, Q.; Izar, P.; Ottoni, E. \& Visalberghi, E. Bearded capuchin monkeys' and a human's efficiency at cracking palm nuts with stone tools: field experiments. Anim. Behav., 79:321-2, 2010

Gardner, E.; Gray, D. \& O' Rahilly, R. Anatomia- Estudo regional do corpo humano. 4a ed. Rio de Janeiro, Editora Guanabara, 1978.

Hollinshead, W. H. Anatomy for surgeons. New York, Hoeber-Harper, 1980.

Holloway, R. L. Endocranial volumes of early African hominids and the role of the brain in human mosaic evolution. J. Hum. Evol., $2: 449-59,1973$

Holloway, R. L. Toward a synthetic theory of human brain evolution. In: Changeux, J. P. \& Chavaillon, J. (Eds). Origins of the Human Brain. Oxford, Clerendon Press, 1995. pp.42-60.

Kindlovits, A. Clínica e Terapêutica em Primatas Neotropicais. Juiz de Fora, Editora UFJF, 1999.

Leung, K. K.; Lu, K. S.; Huang, T. S. \& Hsieh, B. S. Anatomy Instruction in Medical Schools: Connecting the Past and the Future. Adv. Health Sci. Educ. Theory. Pract., 11(2):209-15, 2006.

Letti, N. Anatomia, sua história e seu instrumento de trabalho. Rev. Bras. Otorrino., 38(1):82-8, 1972.

Lopes, R. J. Gênio da selva. Scientific American Brasil, 27:25-32, 2004.

Lyons, A. S. \& Petrucelli, R. J. História da medicina. São Paulo, Editora Manole, 1997.

Malomo, A. O.; Indowu, O. E. \& Osuagwu, F. C. Lesson from history: Human anatomy, from the origin to the Renaissance. Int. J. Morphol., 24(1):99-104, 2006.

Margotta, R. Historia ilustrada da medicina. São Paulo, Manole, 1998.

McL achlan, C. J. \& Patten, D. Anatomy teaching: ghosts of the past, a present and future. Med. Educ., 40:243-53, 2006.

Moore, K. L. \& Dalley, A. F. Anatomia orientada para a clínica. 5. ed. Rio de Janeiro, Guanabara Koogan, 2007.

Napier, J. Hands. Princeton, Princeton University Press, 1980.
Nóbrega, K. S. D. A. \& Tavares, R. A aprendizagem de anatomia: A utilização de mapas conceituais como uma ferramenta instrucional. Belém, XXII Congresso Brasileiro de Anatomia, 2008.

Oliveira, J. N. D. Uma visão Histórica da Medicina. Goiânia, AB Editora, 2005.

O`Malley, C. D. \& Sanders, J. B. C. Andreas Vesalius de Bruxelas, De humani corporis fabrica. Epitome. Tabulae sex: ilustrações e comentarios dos trabalhos anatomicos. São Paulo, Ateliê Editorial, 2002.

Petrucelli, L. J. História da Medicina. São Paulo, Editora Manole, 1997.

Queiroz, C. A. F. O uso de cadáveres humanos como instrumento na construção de conhecimento a partir de uma visão bioética. Dissertação (Mestrado em Ciências Ambientais e Saúde), Goiânia, Universidade Católica de Goiás, 2005.

Resende, M. C.; Tavares, M. C. \& Tomaz, C. Ontogenetic dissociation between habit learning and recognition memory in capuchin monkeys (Cebus apella). Neurobiol. Learn. Mem., 79:19-24, 2003.

Singer, C. Uma breve historia da anatomia e fisiologia desde os gregos até harvey. Campinas, Editora Unicamp, 1996.

Standring, S. Gray's anatomy: The anatomical basis of clinical practice. London, Churchill Livingstone, 2008.

Sugand, K.; Abrahams, P. \& Khurana, A. The Anatomy of Anatomy: A Review for Its Modernization. Anat. Sci. Educ., 3(2):83-93, 2010.

Tobias, P. V. The Brain in Hominid Evolution. New York, Columbia University Press, 1971.

Tobias, P. V.; Changeux, J. P. \& Chavillon, J. Origins of the Human Brain. Oxford, Clarendon Press, 1995.

Van De Graaff, K. M. Pespectiva histórica. Anatomia Humana. 6a ed. Barueri, Manole, 2003.

\section{Correspondence to:}

Tales Alexandre Aversi-Ferreira

Laboratory of Anthropology, Biochemistry

Neuroscience and Primates' Behavior (LABINECOP)

Federal University of Tocantins

Palmas, Tocantins State

BRAZIL

e-mail: aversiferreira@uft.edu.br 